\section{Polyphenols of Mangifera indica modulate arsenite-induced cytotoxicity in a human proximal tubule cell line}

\section{Gabino Garrido, ${ }^{*}$ Nadia Romiti, ${ }^{2}$ Gianfranco Tramonti, ${ }^{3}$ Francisco de la Fuente, ${ }^{1}$ Elisabetta Chieli ${ }^{2}$}

${ }^{1}$ Departamento de Química y Farmacia, Facultad de Ciencias, Universidad Católica del Norte, Antofagasta, Chile,

${ }^{2}$ Dipartimento di Patologia Sperimentale, Sezione di Patologia Generale e Clinica, Facoltà di Medicina e Chirurgia, Università di Pisa, Italia,

${ }^{3}$ Dipartimento di Medicina Interna, Divisione di Nefrologia, Facoltà di Medicina e Chirurgia, Università di Pisa, Italia.
Revista Brasileira de Farmacognosia Brazilian Journal of Pharmacognosy 22(2): 325-334, Mar./Apr. 2012

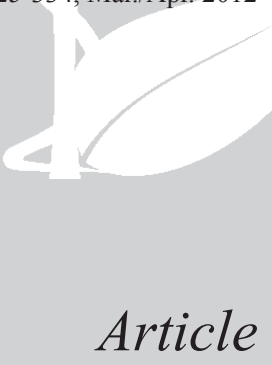

\begin{abstract}
Inorganic arsenic is an ubiquitous environmental contaminant able to cause severe pathologies in humans, including kidney disorders. The possible protective effects of Mangifera indica L., Anacardiaceae, stem bark extract (MSBE) and some mango phenols on the cytotoxicity of arsenite $\left(\mathrm{As}^{\mathrm{III}}\right)$ in the proximal tubule cell line HK-2 was investigated. In cells cultured for $24 \mathrm{~h}$ in presence of $\mathrm{As}^{\mathrm{III}}$, a dose-dependent loss of cell viability occurred that was significantly alleviated by MSBE, followed by gallic acid, catechin and mangiferin. Mangiferin complexed with $\mathrm{Fe}^{+++}$proved more efficacious than mangiferin alone. MSBE and pure phenols increased significantly the cell surviving fraction in clonogenic assays. In cells pretreated with MSBE or phenols for $72 \mathrm{~h}$ the protection afforded by MSBE resulted decreased in comparison with the shorter experiments. Cells pretreated with a subcytotoxic amount of As ${ }^{\text {III }}$ or cultured in continuous presence of low concentration of mangiferin proved to be more resistant to $\mathrm{As}^{\mathrm{III}}$, while cells cultured in presence of albumin resulted more sensitive. Because all the above conditions share changes in expression/activity of P-glycoprotein (P-gp), a transporter potentially involved in arsenic resistance, the capability of $M$. indica phenols

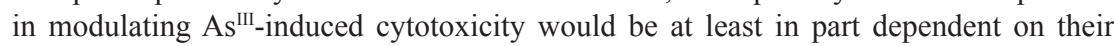
interactions with P-gp.
\end{abstract}

Received 14 Apr 2011

Accepted 20 Sep 2011

Available online 23 Nov 2011

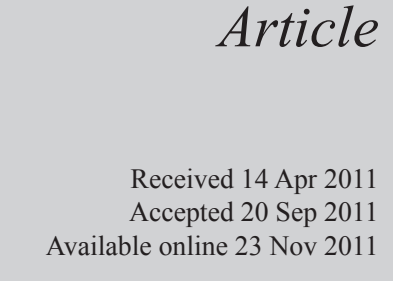

Keywords: arsenic HK-2 cells Mangifera indica mangiferin

P-glycoprotein polyphenols

ISSN 0102-695X i.org/10.1590/S0102$695 \times 2011005000212$

\section{Introduction}

Arsenic (As) is a natural element, which behaves like a metal, and largely diffused throughout the world (Jones, 2007). Arsenic concentration as a pollutant is significantly high in certain countries, including India (Brammer \& Ravenscroft, 2009), Bangladesh (Caussy \& Priest, 2008), China (Sun et al., 2006), Argentina (O’Reilly et al, 2010), Chile (Ferreccio \& Sancha, 2006) and Central Europe (Lindberg et al., 2006).

Contamination by As poses severe problems for human health (Singh et al., 2007). In fact, acute poisoning may be fatal, whereas chronic exposure to relatively low amounts of the metalloid has been proven to induce a variety of non-tumoral and tumoral pathologies (Guha Mazumder, 2008; Gailer, 2009; Rahman et al., 2009). In spite of many studies on As toxicity, the pathogenesis of the toxic effects caused by As at cellular or molecular levels is not fully understood (Hayakawa et al., 2005; Aposhian \& Aposhian, 2006; Gailer, 2009).
However, even if a scientific consensus has not been attained, the main mechanism proposed for Asinduced toxicity is the induction of an oxidative stress, likely mediated by the production of Reactive Oxygen Species (ROS), leading in turn to cell death, apoptosis or DNA damage and cancer (Liu et al., 2001; Lantz \& Hays, 2006; Kitchin \& Conolly, 2010). For this reason, an increasing number of studies both in vivo and in vitro, have been designed to investigate the potential protective effect of antioxidant compounds, including several phytochemicals, against As-induced toxicity (Sinha et al., 2007; Soria et al., 2010; Bera et al., 2010).

Similar studies on polyphenols of Mangifera indica L., Anacardiaceae, to our knowledge, have not yet been performed. In fact, mango phytochemicals have in recent years garnered strong interest for their exceptional activities as antioxidants, anti-inflammatory, immunomodulatory, chemopreventive and anticancer compounds (Masibo \& He, 2009).

The aim of this paper is to investigate whether 
As-induced cytoxicity may be alleviated by mango stem bark extract (MSBE) as well as by the main mango phenols, including mangiferin (MG).

Since the kidney is a main target of arsenic toxicity, we have performed this investigation using the HK-2 proximal tubule cell line, suitable for studying both chemical- and drug-induced nephrotoxicity (Gunness et al., 2010) and already suggested as a convenient model for the study of As effects on the human kidney (Peraza et al., 2003).

Furthermore, because we have recently shown (Chieli et al., 2009; Chieli et al., 2010), that in this cell line $M$. indica polyphenols influenced the activity and/ or expression of P-glycoprotein (P-gp), a membrane transporter potentially involved in As detoxification (Drobná et al., 2010), in the present study we have also explored a possible link between P-gp modulation by mango polyphenols and $\mathrm{As}^{\mathrm{III}}$-induced cytotoxicity.

\section{Material and Methods}

\section{Plant material and chemicals}

Mangifera indica L., Anacardiaceae, was collected from a cultivated field located in the region of Pinar del Rio, Cuba. Voucher specimens of the plant (Code: 41722) were deposited at Herbarium of the Academy of Sciences, by the Institute of Ecology and Systematic, Ministry of Science, Technology and Environment, La Habana, Cuba. Stem bark extract was concentrated by evaporation and spray-dried to obtain a fine brown powder (MSBE), which is used as the standardized active ingredient of Mangifera indica extract formulations (Vimang). It melts at 210-215 ${ }^{\circ} \mathrm{C}$ with decomposition. The chemical composition of MSBE has been characterized by chromatographic (i.e., planar, liquid, and gas) methods, mass spectrometry, nuclear magnetic resonance (NMR), and UV-V spectrophotometry (Núñez-Sellés et al., 2002). The elemental inorganic composition has been determined by Inductively Coupled Plasma (ICP) spectrometry (Núñez Sellés et al., 2007a).

Phenols (mangiferin, catechin, gallic acid and quercetin) and all other chemicals including media and cell culture reagents were purchased from SigmaAldrich (Milan, Italy). All test compounds were stored as aliquots of stock solutions in dimethylsulphoxide (DMSO) at $-20{ }^{\circ} \mathrm{C}$. Before use, they were diluted to final desired concentrations - selected on the basis of pilot studies - and the final concentration of DMSO was never higher than $0.2 \%(\mathrm{v} / \mathrm{v})$. Comparable $\%$ of DMSO was used in experimental controls. Mangiferin/ $\mathrm{Fe}^{+++}$complex was prepared according to Pardo-Andreu et al. (2006).

\section{Cell culture}

The immortalized proximal tubule epithelial cell line from normal adult human kidney (HK-2) was purchased from the American Type Cell Collection (ATCC) and cultured as described in previous papers; for details see Romiti et al. (2002). Passages 32 to 54 were studied. All the tested substances were added, at the desired concentrations, to confluent cells maintained for $48 \mathrm{~h}$ in serum-free medium.

\section{Cytotoxicity assays}

HK-2 cells grown in 96 multiwell plates were pretreated with MSBE or with the individual compounds for $2 \mathrm{~h}$ or $72 \mathrm{~h}$ and then challenged with $\mathrm{As}^{\mathrm{III}}$ at various concentrations. Cell viability was assessed $24 \mathrm{~h}$ later by the neutral red assay (TOX4 kit, Sigma-Aldrich, Milan, Italy), using a microplate reader (Wallac 1420 PerkinElmer Victor 3). The trypan-blue exclusion test was also used for confirmation. In some experiments cells were cultured for two months (12-16 passages in a medium containing MSBE or MG at low concentration) and then their sensitivity to As-induced cytotoxicity was evaluated as above.

\section{Cell apoptosis analysis by fluorescence staining}

The HK-2 cells were cultured in 6-well plates and treated with $\mathrm{As}^{\mathrm{III}}$ in combination with MSBE or individual polyphenols for 6-24 h. Cell apoptosis was evaluated morphologically by in situ uptake of Hoechst 33342. Cells were viewed under fluorescence microscopy (Leica, Milan, Italy) equipped with an online image capture system (Leica DFC320).

\section{Reactive oxygen species (ROS) determination}

The intracellular production of ROS was measured using the $\mathrm{H}_{2} \mathrm{O}_{2}$-sensitive probe dichlorofluorescein diacetate (DCFH-DA).

HK-2 were seeded in 96 multiwell plates and at various time (ranging from 1 to $24 \mathrm{~h}$ ) after the treatment with $\mathrm{As}^{\mathrm{III}}$, alone or in combination with the MSBE or some phenols, cells were incubated with DCFH-DA $\left(10 \mu \mathrm{M}\right.$, in methanol) at $37^{\circ} \mathrm{C}$ for $30 \mathrm{~min}$ in the dark. Monolayers were washed twice with phosphate-buffered saline (PBS) and at last lysed with $0.1 \%$ Triton X-100 to completely solubilize the probe. DCF fluorescence was detected using a microplate reader (Wallac 1420 Perkin-Elmer Victor 3) at excitation and emission wavelengths, 485 and $535 \mathrm{~nm}$, respectively. ROS production by $\mathrm{H}_{2} \mathrm{O}_{2}$ was used as a positive control. 


\section{Clonogenic assay}

To determine HK-2 cell survival after exposure to $\mathrm{As}^{\mathrm{III}}, 100$ cells were seeded in 6-well plates and exposed for $2 \mathrm{~h}$ to $50-200 \mu \mathrm{M} \mathrm{As}^{\mathrm{III}}$ in the absence or presence of polyphenols. MSBE or polyphenols were added 3 hours before As ${ }^{\text {III }}$ treatment. After two weeks of incubation, the colonies were stained with crystal violet and counted.

\section{Western blotting analysis}

Cells were cultured for $72 \mathrm{~h}$ in the presence of a subcytotoxic concentration of $\mathrm{As}^{\mathrm{III}}(2 \mu \mathrm{M})$ or albumin $(15 \mathrm{mg} / \mathrm{mL})$ in order to up- or down-regulate respectively P-gp (Chin et al., 1990; Tramonti et al., 2009). P-gp expression was evaluated in crude membranes of cells as previously described (Romiti et al., 2002), by using the primary monoclonal antibody F4 (Sigma-Aldrich, Milan, Italy). Blots were developed using chemiluminescence detection system and analyzed by densitometry. P-gp expression was also evaluated in cells exposed to $\mathrm{MG}$ or MSBE for two months (see above).

\section{Semiquantitative RT-PCR}

SQRT-PCR of cells treated as above, in order to detect changes in ABCB1 transcripts, was performed as previously described (Romiti et al., 2002). The primer sequences for ABCB1 PCR were as follows: CCCATCATTGCAATAGCAGG (sense) and GTTCAAACTTCTGCTCCTGA (antisense), while the primer sequences for GAPDH PCR were as follows: CGGAGTCAACGGATTTGGTCGTAT (sense) and AGCCTTCTCCATGGTGGTGAAGAC (antisense). PCR products were $157 \mathrm{bp}$ for $\mathrm{ABCB} 1$, and $306 \mathrm{bp}$ for GAPDH, respectively.

\section{Statistical analysis}

The results are presented as the mean $\pm \mathrm{SD}$ of at least three independent experiments. Graphs were created by using GraphPad Prism software and statistical significance was calculated using Student's t-test or ANOVA followed by a post hoc test, when appropriate. Levels of $p<0.05$ were considered statistically significant.

\section{Results}

In HK-2 cells exposed to As ${ }^{\mathrm{III}}$ a dose and timedependent loss of viability occurred. Figure 1 shows the results obtained by the neutral red test after $24 \mathrm{~h}$. When cells were pretreated with MSBE ( $2 \mathrm{~h})$ combined with $A s^{\text {III }}$, a significant dose-dependent protection was observed (Figure 1A).
Because MSBE is a very complex mixture containing a large amount of polyphenols (Núñez et al., 2002), we tested some individual phenolic ingredients of MSBE for their potential ability to protect HK-2 cells against arsenic-induced cytotoxicity. Therefore, cells were pretreated for $2 \mathrm{~h}$ with mangiferin (MG), a glucosylxanthone representing the main polyphenol of MSBE (about 10-15\%), catechin (CTCH), the second polyphenol of MSBE, gallic acid (GA) or quercetin (QCT) and then exposed to $\mathrm{As}^{\mathrm{III}}$ for $24 \mathrm{~h}$.

The relative dose-response curves (Figure 1B-E), show that MG, CTCH and GA, are able to mitigate the $\mathrm{As}^{\mathrm{III}}$-induced toxicity although with different effectiveness. In particular, MG showed a very moderate effect and resulted protective only in a very narrow range of As ${ }^{\mathrm{III}}$ concentrations, while both $\mathrm{CTCH}$ and GA showed better cytoprotective effects.

On the other hand, QCT did not produce any alleviating effect, on the contrary, it showed a slight cytotoxicity at concentration $25 \mu \mathrm{M}$ (Figure 1E) and a clear cytotoxicity at higher concentrations (results not shown), according to the findings of Soria et al. (2010). Some studies have shown that MG may be endowed with a more efficient antioxidant activity when it is complexed with $\mathrm{Fe}^{+++}$(Pardo-Andreu et al., 2006). Therefore, also this complex was investigated for its potential protective effects against $\mathrm{As}^{\mathrm{III}}$-induced toxicity. Figure $1 \mathrm{~F}$ shows that a significant difference exists in the protection against As ${ }^{\mathrm{III}}$ afforded by the $\mathrm{MG} / \mathrm{Fe}^{+++}$complex as compared with MG alone (Figure 1B).

Summing up, cytotoxicity studies show that the $\mathrm{As}^{\mathrm{III}}$-induced injury to the HK-2 cells is mitigated to some extent by all the investigated antioxidants, but the individual phenolic components of MSBE are much less effective than the whole mixture.

Morphological examination of cells confirmed the results of cytotoxicity test obtained by the neutral red assay. In particular, most cells exposed to high $\mathrm{As}^{\mathrm{III}}$ concentrations detached from the plate culture, showing the typical features of apoptosis. By contrast, cells treated with $\mathrm{MSBE}+\mathrm{As}^{\mathrm{II} I}$ remained attached, showing pleomorphic features ranging from normal to clearly apoptotic cell. The uptake of neutral red inside the cells, a hallmark of viability, was also checked at microscopical level (Figure 2).

Individual polyphenols showed a variable reduction of $\mathrm{As}^{\mathrm{III}}$-induced apoptosis in the cells but this protection was always lower than observed for MSBE (images not shown).

To confirm the above results, also the clonogenic assay was used, because it is regarded as the gold standard for screening toxicity of chemical or physical agents (Franken et al., 2006).

Figure 3 shows that all treatments are protective, resulting in a significant elevation of cell survival 
when compared with the cells treated with $\mathrm{As}^{\mathrm{III}}$ alone; in particular, the effects of $\mathrm{MG}$ and $\mathrm{MG} / \mathrm{Fe}^{+++}$appear similar to those of MSBE. With regards to the possible mechanisms of $\mathrm{As}^{\mathrm{III}}$-induced cell damage, we were not able to detect the formation of ROS in HK-2 cells, at least at the times investigated $\left(1,6\right.$, or $24 \mathrm{~h}$ after $\mathrm{As}^{\mathrm{III}}$ exposure), by using the $\mathrm{H}_{2} \mathrm{O}_{2}$ sensitive probe DCFDA.

However, the treatment of HK-2 cells with MG or MSBE alone, or combined with $\mathrm{As}^{\mathrm{III}}$, decreased the fluorescence of DCF in comparison to control. Figure 4 shows the results for a $6 \mathrm{~h}$ treatment (superimposable to those obtained at the other times, not shown).
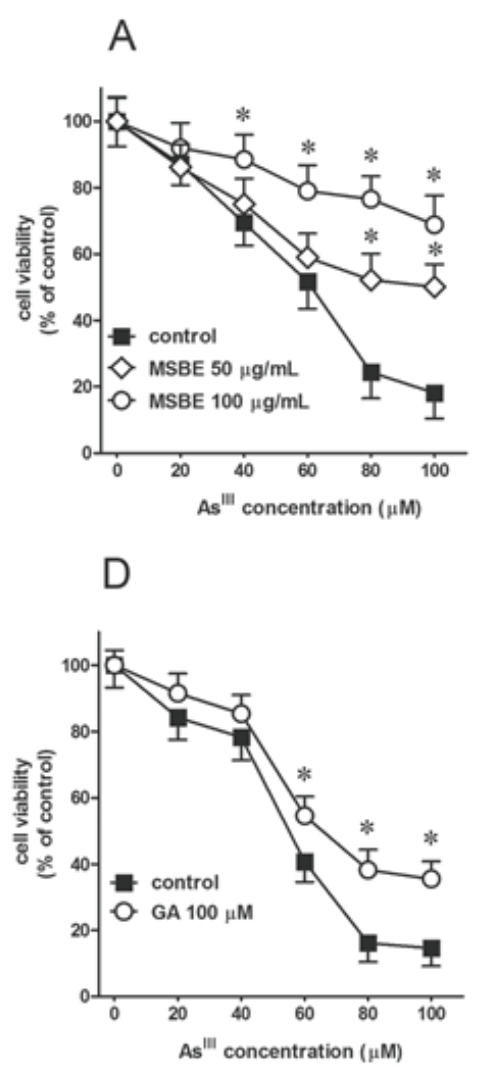

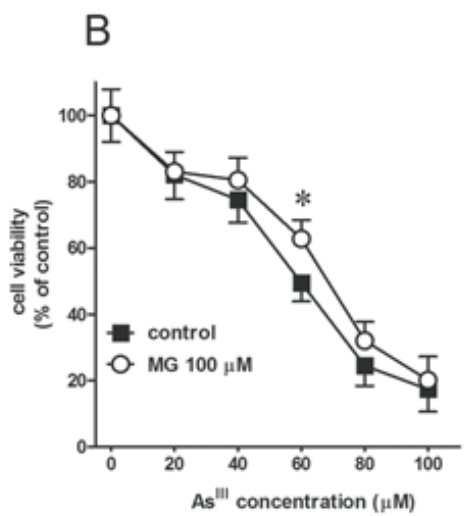

$\mathrm{E}$

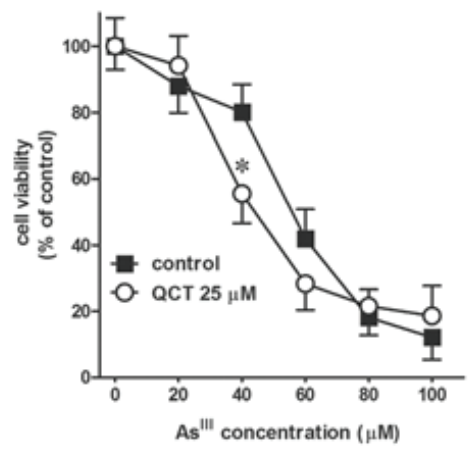

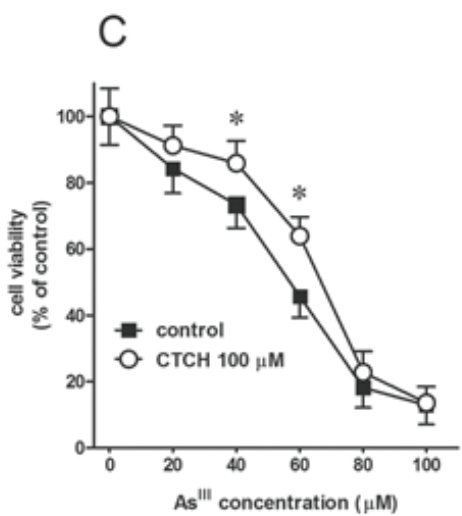

$\mathrm{F}$

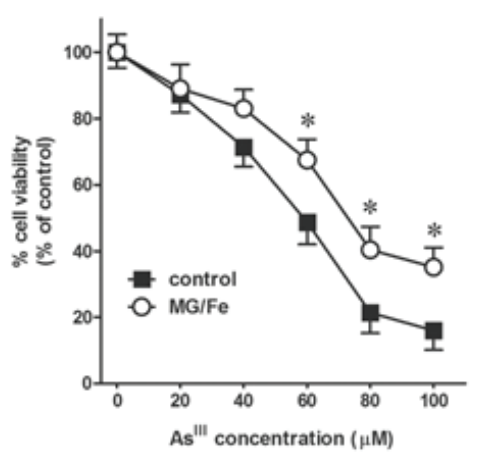

Figure 1. Cytotoxicity of $\mathrm{As}^{\mathrm{III}}$ in HK-2 cells cultured in absence or in presence of A. M. indica stem bark extract (MSBE); B. mangiferin (MG); C. catechin $(\mathrm{CTCH})$; D. gallic acid (GA); E. quercetin, and F. MG/Fe ${ }^{++}$complex. MSBE or polyphenols were added to cell cultures $2 \mathrm{~h}$ before treating with $\mathrm{As}^{\mathrm{III}}(20-100 \mu \mathrm{M})$ and viability was assessed by the neutral red method after $24 \mathrm{~h}$. Data represent the mean $\pm \mathrm{SD}$ from at least three independent experiments for each treatment. *means a significant difference $(p<0.05)$ from the corresponding value of controls (cells exposed to As ${ }^{\mathrm{III}}$ alone) determined by student's t-test.
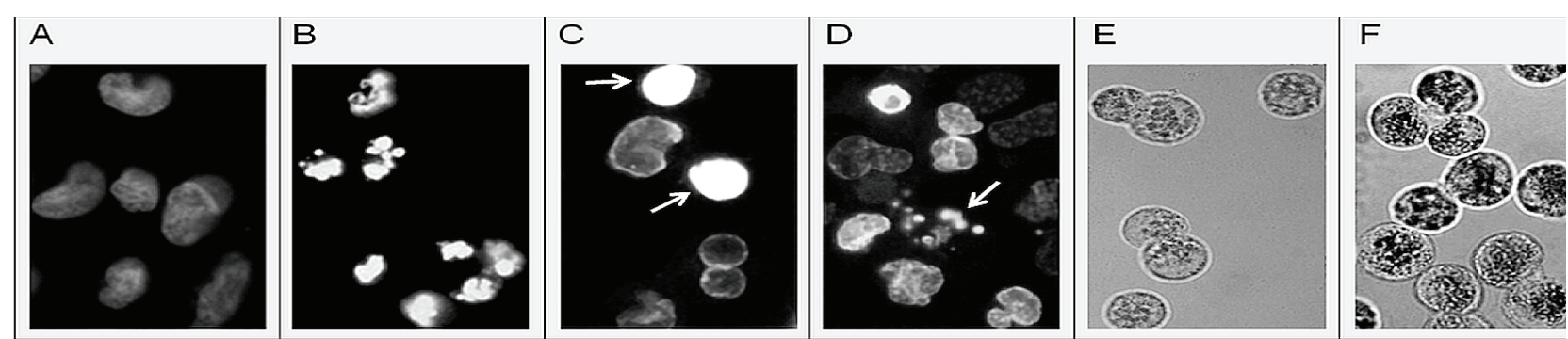

Figure 2. Effects of $\mathrm{As}^{\mathrm{III}}(100 \mu \mathrm{M})$ and $\mathrm{MSBE}(100 \mu \mathrm{g} / \mathrm{mL})$ on HK-2 cells morphology. (Hoechst 33342 staining, $\left.400 \mathrm{x}\right)$. Atypical features of cells observed in control group; B. many cells treated with As ${ }^{\mathrm{III}}$ showed after $6 \mathrm{~h}$, the typical late apoptotic nuclear morphology; C. HK-2 cells treated with MSBE $+\mathrm{As}^{\mathrm{III}}(6 \mathrm{~h})$ showed either cells with typical early apoptotic morphology (cell and cromatin condensation, arrows), or no typical apoptotic cells; D. cells in cultures treated with MSBE+As ${ }^{\mathrm{III}}$ for $24 \mathrm{~h}$, morphology included normal, condensed and apoptotic cells with fragmented nuclei (arrows). HK-2 cells were stained with $5 \mu \mathrm{M}$ Hoechst 33342 for $15 \mathrm{~min}$. Fluorescence was detected on a Leica fluorescence microscope equipped with an online image capture system, using a DAPI barrier filter set; E. image of $\mathrm{As}^{\mathrm{III}}$ - treated cells and F. MSBE+As ${ }^{\mathrm{III}}$ - treated cells, stained with neutral red (bright field, original magnification: 400x): the impairment of the ability of cells to incorporate and bind the supravital dye, caused by As, was prevented (decreased) by MSBE. 
A

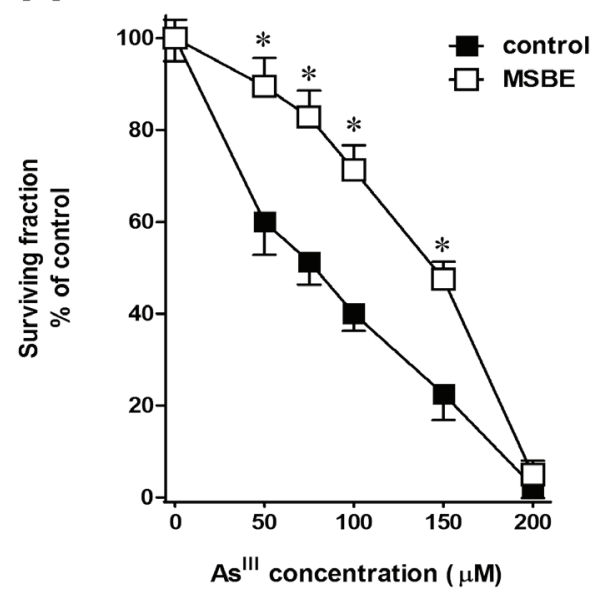

C

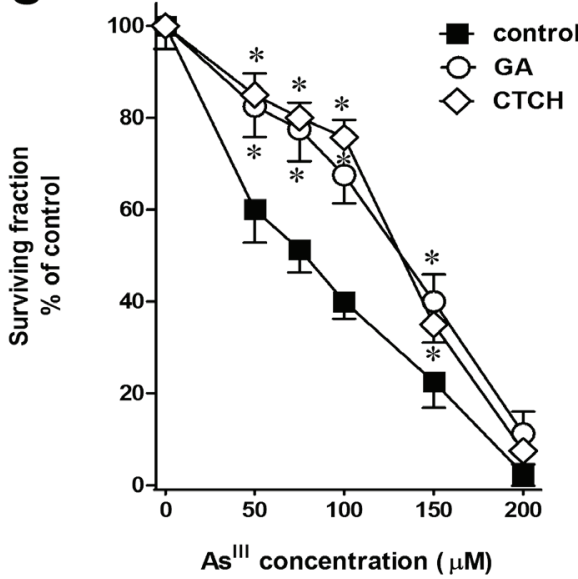

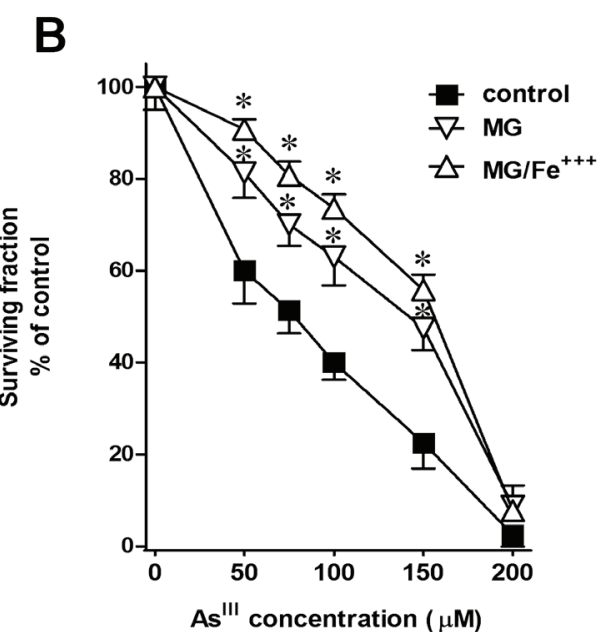

D

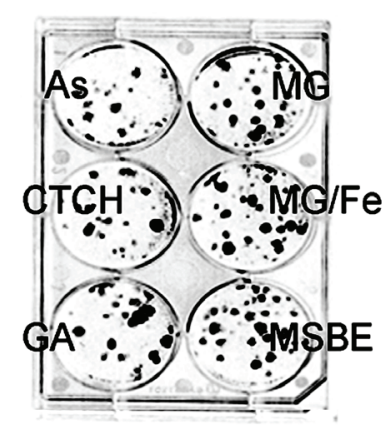

Figure 3. Effect of $M$. indica stem bark extract (MSBE, $100 \mu \mathrm{g} / \mathrm{mL}$ ) or mangiferin (MG, $100 \mu \mathrm{M}$ ), $\mathrm{MG} / \mathrm{Fe}^{+++}$complex, gallic acid (GA), and catechin (CTCH), on survival of HK-2 cells treated with different concentrations of $\mathrm{As}^{\mathrm{III}}$ as assessed by clonogenic assay. Data represent the mean $\pm \mathrm{SD}$ of three independent experiments. The graph has been subdivided in three parts in order to avoid superimposition of curves. Right: viable colonies stained with crystal violet. *means a significant difference $(p<0.05)$ respect to the control group, determined by student's t-test.

In a second set of experiments $\mathrm{As}^{\mathrm{III}}$ cytotoxicity was assessed in cells pretreated for $72 \mathrm{~h}$ with MSBE or the related individual polyphenols.

Figure 5 shows that the protection against $\mathrm{As}^{\mathrm{III}}$ cytotoxicity was significantly decreased for MSBE (72 h), in comparison with the results in Figure $1(24 \mathrm{~h})$. The efficacy of MG resulted slightly increased, while that of $\mathrm{MG} / \mathrm{Fe}^{+++}$or $\mathrm{CTCH}$ did not change substantially. The protective effects of GA resulted a bit decreased as compared with the $24 \mathrm{~h}$ experiments. Also in this case QCT concentration higher than $25 \mu \mathrm{M}$ in the presence of $\mathrm{As}^{\mathrm{III}}$ resulted in elevated cytolethality.

Since MSBE and its phenols modulate P-gp expression, we performed some experiments in order to ascertain if the level of P-gp could affect the sensitivity of HK-2 cells to As ${ }^{\mathrm{III}}$ (Figure 6). Cells pretreated for 72 $\mathrm{h}$ with $A s^{\mathrm{III}}$ at a subcytotoxic dose $(2 \mu \mathrm{M})$ in order to induce P-gp (Chin et al., 1990) and then challenged with cytotoxic concentration of As ${ }^{\text {III }}$, resulted more resistant, whereas cells cultured in the presence of albumin, a condition in which P-gp is markedly downregulated (Tramonti et al., 2009), proved to be less resistant (Figure 6A). The sensitivity of cells to As-induced cytotoxicity was correlated with the relative expression of P-gp (Figure 6B).

Furthermore, when the cells were cultured for two months in the continuous presence of low concentrations of MG $(10 \mu \mathrm{M})$ or MSBE $(10 \mu \mathrm{g} / \mathrm{mL})$, they became more resistant to a challenging dose of $\mathrm{As}^{\mathrm{III}}$ (Figure 6C). In particular, the long term exposure to $\mathrm{MG}$ caused also a slight, but significant increase in P-gp expression (Figure $6 \mathrm{D})$. 


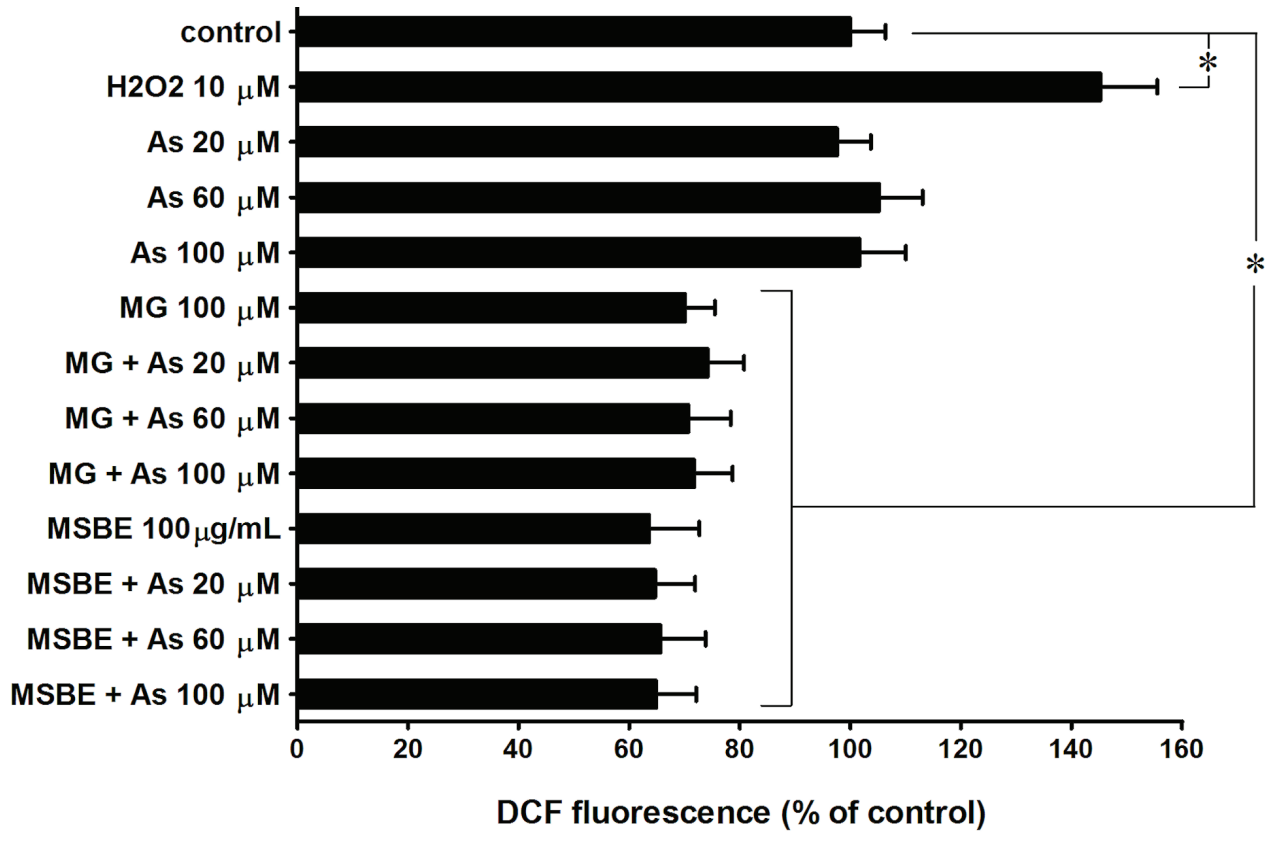

Figure 4. Detection of intracellular ROS using the oxidative-sensitive fluorescent probe, DCFH-DA. Cells were seeded into 96-well plates and incubated with MSBE $(100 \mu \mathrm{g} / \mathrm{mL})$ or MG $(100 \mu \mathrm{M})$ alone or in combination with As ${ }^{\mathrm{III}}$ during 6 hours. After incubation, DCFH-DA was added and after 30 min intracellular ROS generation was measured using a microplate fluorescence reader. $\mathrm{H}_{2} \mathrm{O}_{2}(10 \mu \mathrm{M})$ was used as positive control. Bars represent the change in mean fluorescence intensity $(\%$ of control $) \pm \mathrm{SD}$ from three independent experiments. ${ }^{*}$ means a significant difference $(p<0.05)$ respect to the control group, determined by one-way ANOVA and Dunnett's post- test. The results were compared with fluorescence microscopy observations.
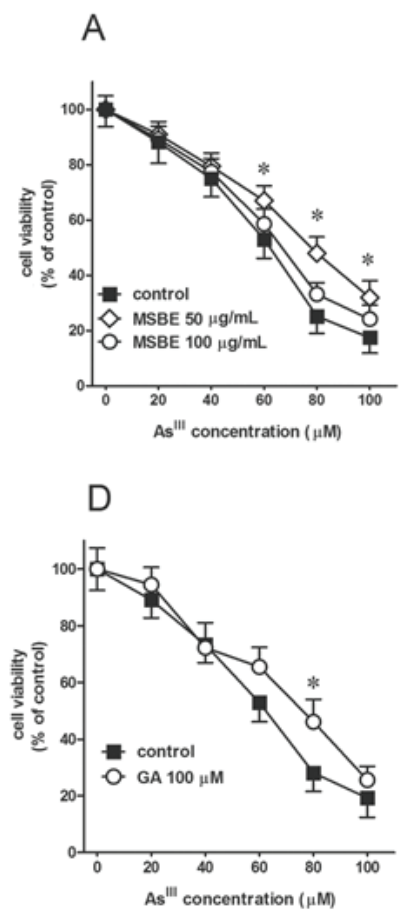
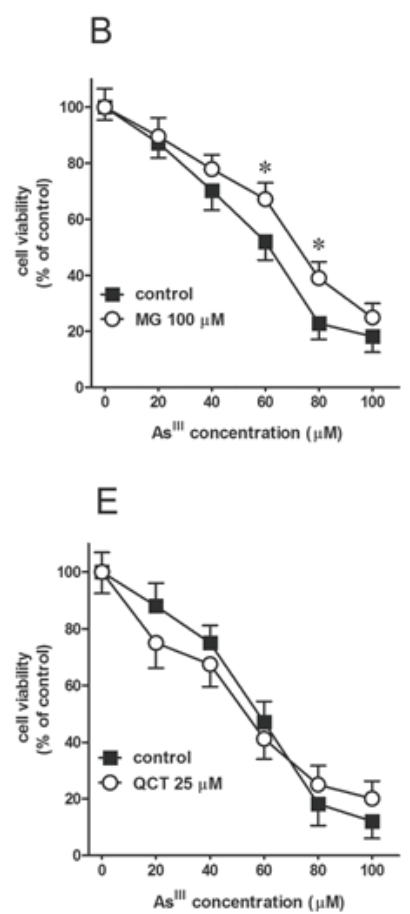
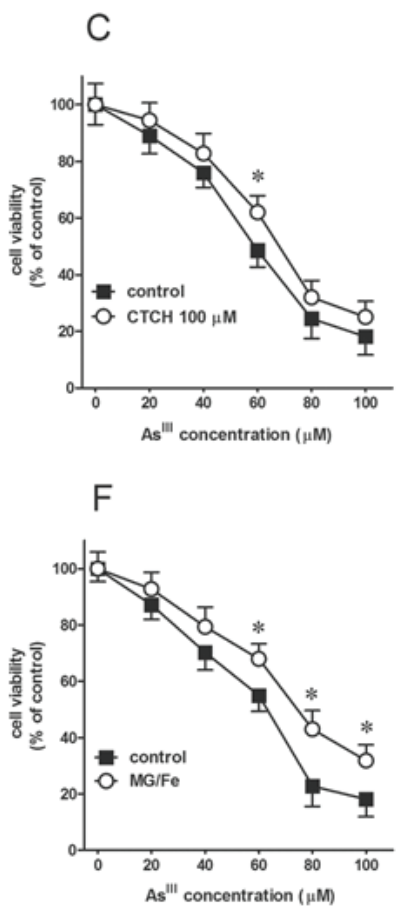

Figure 5. Cytotoxicity of $\mathrm{As}^{\mathrm{III}}$ in HK-2 cells previously cultured for $72 \mathrm{~h}$ in absence or in presence of A. M. indica stem bark extract (MSBE); B. mangiferin (MG); C. catechin $(\mathrm{CTCH})$; D. gallic acid (GA); E. quercetin (QCT) or F. MG/Fe ${ }^{+++}$. Viability was assessed by the neutral red method $24 \mathrm{~h}$ after the addition of $\mathrm{As}^{\mathrm{III}}$. Data represent the mean $\pm \mathrm{SD}$ of at least three independent experiments for each treatment. *means a significant difference $(p<0.05)$ from the corresponding value of controls (cells exposed to As ${ }^{\mathrm{III}}$ alone), determined by student's t-test. 
A

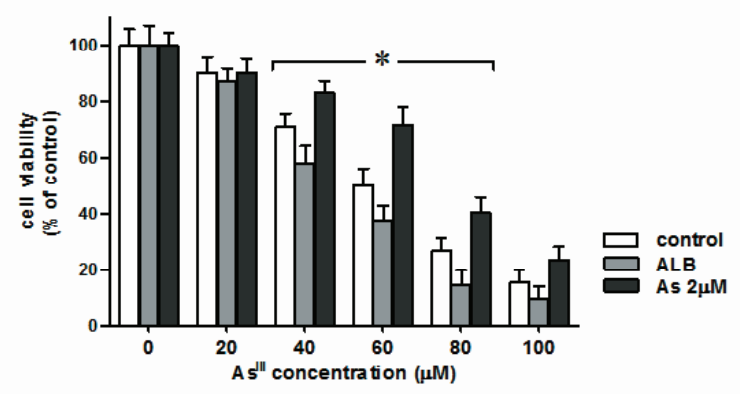

C

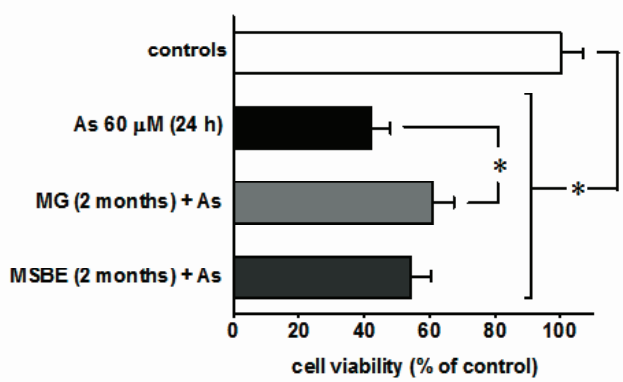

B

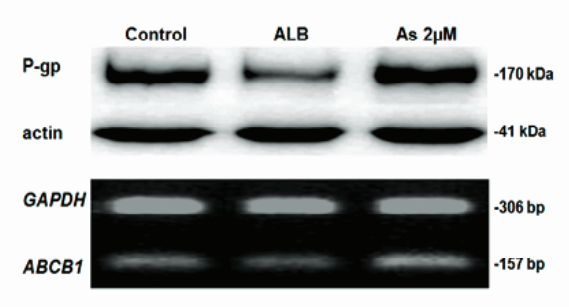

D

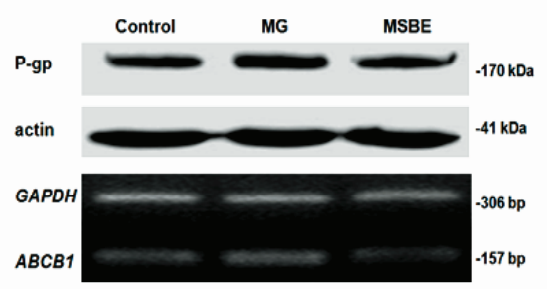

Figure 6. A. Cytotoxicity of As ${ }^{\mathrm{III}}$ in HK-2 cells previously cultured for $72 \mathrm{~h}$ in medium containing $15 \mathrm{mg} / \mathrm{mL}$ albumin (Pgpdepleted) or previously cultured for $72 \mathrm{~h}$ in presence of a subcytotoxic (P-gp inducing) As ${ }^{\mathrm{III}}$ concentration $(2 \mu \mathrm{M})$. Viability was assessed by the neutral red method $24 \mathrm{~h}$ after the treatment with $\mathrm{As}^{\mathrm{III}}(20-100 \mu \mathrm{M})$; B. Amount of P-gp and ABCB1 mRNA in the same cells, determined by western blot (upper panel) and SQRT-PCR (lower panel), respectively; C. Viability of HK-2 cells cultured in medium containing low concentrations of MG $(10 \mu \mathrm{M})$ or $\operatorname{MSBE}(10 \mathrm{mg} / \mathrm{mL})$ during two months and then challenged with $\mathrm{As}^{\mathrm{III}}(60 \mu \mathrm{M})$ for $24 \mathrm{~h}$; D. Amount of P-gp and ABCB1 mRNA in the same cells. Data represent the mean $\pm \mathrm{SD}$ of three independent experiments. *means a significant difference $(p<0.05)$ determined by one-way ANOVA and Bonferroni's post-test.

\section{Discussion}

The beneficial properties of MSBE, an extract from the stem bark of Mangifera indica L., Anacardiaceae registered in Cuba under the brand name of Vimang ${ }^{\circledR}$, as well as those of Mangifera indica derived polyphenols have been reported in numerous studies (Garrido et al., 2004, 2006, 2007; Núñez-Sellés et al., 2007b; PardoAndreu et al., 2008; Masibo \& He, 2009).

In particular, the MSBE antioxidant capacity, ROS scavenging ability and consequent protection have been verified in several models of oxidative damage both in vitro and in vivo and in different organs and tissues (Garrido et al., 2008; Rodeiro et al., 2007, 2008; PardoAndreu et al., 2008; Martinez-Sanchez et al., 2000, 2001). Since arsenic is generally believed to induce cell damage by triggering cellular events, such as ROS production, leading to oxidative stress (Lantz \& Hays, 2006), we may hypothesize that MSBE, behaving as a strong antioxidant, could suppress these events.

However, in the literature, there are several conflicting results about As-induced ROS formation (Morales et al., 2009; Naranmandura et al., 2009; Catanzaro et al., 2010) and ourselves were not able to demonstrate ROS increase by As in our experimental setting.

On the other hand, an interesting observation was that both MSBE and MG were able to decrease the basal fluorescence of the ROS indicator DCF, suggesting a decrease in endogenous $\mathrm{H}_{2} \mathrm{O}_{2}$ generation, a mechanism possibly involved in the mitigation of As-induced cytotoxicity in cells pretreated with the extract. The beneficial effects of MSBE have mainly been ascribed to its main polyphenol, the xanthone $\mathrm{MG}$ that has earned the name of "super-antioxidant" (Masibo \& He, 2009).

Surprisingly, MG was relatively weak in counteracting the $24 \mathrm{~h} \mathrm{As}{ }^{\mathrm{III}}$-induced cytotoxicity in our cell model. On the other hand, in most of the studies reported in literature, the protection conferred by MSBE was higher than that conferred by MG. The possibility of an additive action between MG and the other phenols and/or compounds contained in MSBE, might explain 
the increased efficacy of MSBE vs. MG alone (PardoAndreu et al., 2006). This hypothesis agrees with our results showing that the flavan-3-ol $\mathrm{CTCH}$, as well as the phenolic acid GA, both contained in MSBE, are able to protect against $\mathrm{As}^{\mathrm{III}}$-induced cytotoxicity.

Interestingly, the capability of $\mathrm{MG}$ in improving cell survival of HK-2 cells challenged with $\mathrm{As}^{\mathrm{III}}$, was significantly increased when the xanthone was complexed with $\mathrm{Fe}^{+++}$. MG/Fe $\mathrm{Fe}^{+++}$complex has been shown to protect $20 \%$ more than MG alone, hepatocytes from reactive oxygen species-mediated hypoxia/reoxygenation injury, likely by its strong ability to scavenge superoxide radicals (Pardo-Andreu et al., 2006). Therefore, although indirectly, this finding suggests that oxidative stress is involved in As-induced cytotoxicity in HK-2 cells.

It could be remarked that in the clonogenic assay, that measures aspects of cytotoxicity distinct from those evidentiated by the viability test, i.e. the residual potential of cells to grow, vs. metabolic alterations, there are not strong differences in the protective ability among $\mathrm{MSBE}, \mathrm{MG}$ and $\mathrm{MG} / \mathrm{Fe}$. However, $\mathrm{MG} / \mathrm{Fe}$ is still a bit more effective than $\mathrm{MG}$ alone.

In the more long-lasting (three days) experiments of the present study, an interesting finding was the decrease of protection afforded by MSBE and, vice-versa, the relative increase in the protective effect of $\mathrm{MG}$.

Previously, we showed that MG-treated cells become progressively more resistant to cyclosporine A-induced cytotoxicity (Chieli et al., 2010). This effect was attributed at least in part to the MG-induced upregulation of P-gp expression/activity in HK-2 cells. In fact, P-gp plays a key role in the detoxification of several drugs substrates, including CsA (Anglicheau et al., 2006).

A role of membrane transporters, including P-gp, has been suggested in the cellular handling/detoxification of As (Drobná et al., 2010) and ABCB1 (MDR-1) upregulation by arsenic has been described in literature (Chin et al., 1990; Kioka et al., 1992; Maitra \& Hamilton, 2005). In the present study we demonstrate that HK-2 cells cultured in the presence of subcytotoxic concentration of $\mathrm{As}^{\mathrm{III}}$ show an increased amount of both ABCB1 mRNA and P-gp and, in parallel, are more tolerant to $24 \mathrm{~h} \mathrm{As}{ }^{\mathrm{III}}$ exposure.

Therefore, the slightly increased efficiency of $\mathrm{MG}$ in mitigating As-cytotoxicity observed after a $72 \mathrm{~h}$ treatment could be temptatively ascribed to the upregulation of P-gp induced by the xanthone.

Present data also show that HK-2 cells, in which P-gp expression was heavily depressed by protein overload (Tramonti et al., 2009) are more sensitive to Asinduced cytotoxicity.

Accordingly, MSBE, which very efficiently protects against $\mathrm{As}^{\mathrm{III}}$ in experiments with $24 \mathrm{~h}$ of exposure, produces a milder protection after $72 \mathrm{~h}$, when
P-gp expression appears strongly downregulated, and its activity is inhibited (Chieli et al., 2010).

Interestingly, this inverse correlation between P-gp expression and sensitivity to As was also maintained in the case of two months of exposure of cells to very low concentrations of MG.

In conclusion, for the first time we show that a mango stem bark extract and some of its phenolic components may to some extent alleviate the cytotoxicity of arsenite in the proximal tubule cells HK-2 and that P-glycoprotein could play a possible role in the modulation of As toxicity in our experimental model. In perspective, mango polyphenols interactions with this and/or other membrane transporters, possibly modifying the cell response to As, would be taken into account in future studies, both in the medical and ecotoxicological field.

\section{References}

Anglicheau D, Pallet N, Rabant M, Marquet P, Cassinat B, Méria P, Beaune P, Legendre C, Thervet E 2006. Role of P-glycoprotein in cyclosporine cytotoxicity in the cyclosporine-sirolimus interaction. Kidney Int 70: 1019-1025.

Aposhian HV, Aposhian MM 2006. Arsenic toxicology: Five questions. Chem Res Toxicol 19: 1-15.

Bera AK, Rana T, Das S, Bandyopadhyay S, Bhattacharya D, Pan D, De S, Das SK 2010. L-Ascorbate protects rat hepatocytes against sodium arsenite-induced cytotoxicity and oxidative damage. Hum Exp Toxicol 29: 103-111.

Brammer H, Ravenscroft P 2009. Arsenic in groundwater: A threat to sustainable agriculture in South and South-east Asia. Environ Int 35: 647-654.

Catanzaro I, Schiera G, Sciandrello G, Barbata G, Caradonna F, Proia P, Di Liegro I 2010. Biological effects of inorganic arsenic on primary cultures of rat astrocytes. Int J Mol Med 26: 457-462.

Caussy D, Priest ND 2008. Introduction to arsenic contamination and health risk assessment with special reference to Bangladesh. Rev Environ Contam T 197: 1-15.

Chieli E, Romiti N, Rodeiro I, Garrido G 2009. In vitro effects of Mangifera indica and polyphenols derived on ABCB1/P-glycoprotein activity. Food Chem Toxicol 47: 2703-2710.

Chieli E, Romiti N, Rodeiro I, Garrido G 2010. In vitro modulation of $\mathrm{ABCB} 1 / \mathrm{P}$-glycoprotein expression by polyphenols from Mangifera indica. Chem Biol Interact 186: 287-294.

Chin K V, Tanaka S, Darlington G, Pastan I, Gottesman MM 1990. Heat shock and arsenite increase expression of the multidrug resistance (MDR1) gene in human renal carcinoma cells. J Biol Chem 265: 221-226.

Drobná Z, Walton FS, Paul DS, Xing W, Thomas DJ, Stýblo M 
2010. Metabolism of arsenic in human liver: the role of membrane transporters. Arch Toxicol 84: 3-16.

Ferreccio C, Sancha AM 2006. Arsenic exposure and its impact on health in Chile. J Health Popul Nutr 24: 164-175.

Franken NA, Rodermond HM, Stap J, Haveman J, van Bree C 2006. Clonogenic assay of cells in vitro. Nat Protoc 1: 2315-2319.

Gailer J 2009. Chronic toxicity of As(III) in mammals: the role of (GS)(2)AsSe(-). Biochimie 91: 1268-1272.

Garrido G, González D, Lemus Y, Delporte C, Núñez-Sellés AJ, Delgado R 2006. Protective effects of a standard extract of Mangifera indica L. (VIMANG) against mouse ear edemas and its inhibition on eicosanoids production in J774 murine macrophages. Phytomedicine 13: 412418.

Garrido G, González D, Romay C, Núñez-Sellés AJ, Delgado R 2008. Scavenger effect of a mango (Mangifera indica L.) food supplement's active ingredient on free radicals produced by human polymorphonuclear cells and hypoxanthine-xanthine oxidase chemiluminescence systems. Food Chem 107: 1008-1014.

Garrido G, González D, Lemus Y, García D, Lodeiro L, Quintero G, Delporte C, Núñez-Sellés AJ, Delgado R 2004. In vivo and in vitro anti-inflammatory activity of Mangifera indica L. extract (VIMANG ${ }^{\circledR}$ ). Pharmacol Res 50: 143-149.

Garrido G, Martínez-Sánchez G, Pardo-Andreu G, GarcíaRivera D, Hernández-Casaña P, Rodeiro-Guerra I, Guevara-García M, Delgado-Hernández R, NúñezSellés, AJ 2007. Recent advances in the research \& development of an aqueous stem bark extract obtained from Mangifera indica L. In: Recent Developments in Medicinal Plant Research, (Capasso A., Ed.) p. 69-82.

Guha Mazumder DN 2008 Chronic arsenic toxicity \& human health. Indian J Med Res 128: 436-447.

Gunness P, Aleksa K, Kosuge K, Ito S, Koren G 2010. Comparison of the novel HK-2 human renal proximal tubular cell line with the standard LLC-PK1 cell line in studying drug-induced nephrotoxicity. Can J Physiol Pharm 88: 448-455.

Hayakawa T, Kobayashi Y, Cui X, Hirano S 2005. A new metabolic pathway of arsenite: arsenic-glutathione complexes are substrates for human arsenic methyltransferase Cyt19. Arch Toxicol 79: 183-191.

Kioka N, Yamano Y, Komano T, Ueda K 1992. Heat-shock responsive elements in the induction of the multidrug resistance gene (MDR1). FEBS Letters 301: 37-40.

Kitchin KT, Conolly R 2010. Arsenic-induced carcinogenesisoxidative stress as a possible mode of action and future research needs for more biologically based risk assessment. Chem Res Toxicol 23: 327-335.

Jones FT 2007. A broad view of arsenic. Poult Sci S 86: 2-14.

Lantz RC, Hays AM 2006. Role of oxidative stress in arsenicinduced toxicity. Drug Metab Rev 38: 791-804.

Lindberg AL, Goessler W, Gurzau E, Koppova K, Rudnai P,
Kumar R, Fletcher T, Leonardi G, Slotova K, Gheorghiu E, Vahter M 2006. Arsenic exposure in Hungary, Romania and Slovakia. J Environ Monitor 8: 203-208.

Liu J, Chen H, Miller DS, Saavedra JE, Keefer LK, Johnson DR, Klaassen CD, Waalkes MP 2001. Overexpression of glutathione S-transferase II and multidrug resistance transport proteins is associated with acquired tolerance to inorganic arsenic. Mol Pharmacol 60: 302-309.

Maitra R, Hamilton JW 2005. Arsenite regulates cystic fibrosis transmembrane conductance regulator and P-glycoprotein: Evidence of pathway independence. Cell Physiol Biochem 16: 109-118.

Martinez-Sánchez G, Candelario-Jalil E, Giuliani A, León OS, Sam S, Delgado R, Núñez-Sellés AJ 2001. Mangifera indica L. extract (Vimang) reduces ischemia-induced neuronal loss and oxidative damage in the gerbil brain. Free Radical Res 35: 465-473.

Martínez-Sánchez G, Delgado R, Nuñez-Sellés AJ, Pérez G, Garrido G, León OS 2000. Evaluation of the in vitro antioxidant activity of Mangifera indica L. extract (Vimang ${ }^{\circledR}$ ). Phytother Res 14: 424-427.

Masibo M, He Q 2009. Mango bioactive compounds and related nutraceutical properties. Food Rev Int 25: 346-370.

Morales AA, Gutman D, Cejas PJ, Lee KP, Boise LH 2009. Reactive oxygen species are not required for an arsenic trioxide-induced antioxidant response or apoptosis. $J$ Biol Chem 284: 12886-12895.

Naranmandura H, Ogra Y, Iwata K, Lee J, Suzuki KT, Weinfeld M, Le XC 2009. Evidence for toxicity differences between inorganic arsenite and thioarsenicals in human bladder cancer cells. Toxicol Appl Pharma 238: 133140.

Núñez-Sellés AJ, Vélez Castro HT, Agüero-Agüero J, González-González J, Naddeo F, De Simone F, Rastrelli L 2002. Isolation and quantitative analysis of phenolic antioxidants, free sugars and polyphenols from mango (Mangifera indica L.) stem bark aqueous decoction used in Cuba as a nutritional supplement. J Agr Food Chem 50: 762-766.

Núñez-Sellés AJ, Delgado-Hernandez R, Garrido-Garrido G, Garcia-Rivera D, Guevara-Garcia M, PardoAndreu GL 2007b. The paradox of natural products as pharmaceuticals. Experimental evidences of a mango stem bark extract. Pharmacol Res 55: 351-358.

Núñez AJ, Durruthy MD, Rodríguez E, Nieto L, Nicolais V, Rastrelli L 2007a. Comparison of major and trace element concentration in sixteen varieties of Cuban mango stem bark (Mangifera indica L.). J Agr Food Chem 55: 2176-2181.

O'Reilly J, Watts MJ, Shaw R A, Marcilla AL, Ward NI 2010. Arsenic contamination of natural waters in San Juan and La Pampa, Argentina. Environ Geochem Hlth 32: 491-515.

Pardo-Andreu GL, Sánchez-Baldoquín C, Avila-González R, Delgado R, Naal Z, Curti, C 2006. Fe(III) improves 
antioxidant and cytoprotecting activities of mangiferin. Eur J Pharmacol 547: 31-36.

Pardo-Andreu GL, Barrios MF, Curti C, Hernández I, Merino N, Lemus Y, Martínez I, Riaño A, Delgado R 2008. Protective effects of Mangifera indica L extract (Vimang), and its major component mangiferin, on iron-induced oxidative damage to rat serum and liver. Pharmacol Res 57: 79-86.

Peraza MA, Carter DE, Gandolfi AJ 2003. Toxicity and metabolism of subcytotoxic inorganic arsenic in human renal proximal tubule epithelial cells (HK-2). Cell Biol Toxicol 19: 253-264.

Rahman MM, Ng JC, Naidu R, 2009. Chronic exposure of arsenic via drinking water and its adverse health impacts on humans. Environ Geochem Hlth 31: 189-200.

Rodeiro I, Donato MT, Jiménez N, Garrido G, Delgado R, Gómez-Lechón MJ 2007. Effects of Mangifera indica L. aqueous extract (Vimang) on primary culture of rat hepatocytes. Food Chem Toxicol 45: 2506-2512.

Rodeiro I, Donato MT, Martínez I, Hernández I, Garrido G, González-Lavaut JA, Menéndez R, Laguna A, Castell JV, Gómez-Lechón MJ 2008. Potential hepatoprotective effects of new Cuban natural products in rat hepatocytes cultured. Toxicol in Vitro 22: 1242-1249.

Romiti N, Tramonti G, Chieli E, 2002. Influence of different chemicals on MDR-1 P-glycoprotein expression and activity in the HK-2 proximal tubular cell line. Toxicol
Appl Pharm 183: 83-91.

Singh N, Kumar D, Sahu AP 2007. Arsenic in the environment: effects on human health and possible prevention. $J$ Environ Biol 28: 359-365.

Sinha D, Dey S, Bhattacharya RK, Roy M 2007. In vitro mitigation of arsenic toxicity by tea polyphenols in human lymphocytes. J Environ Pathol Tox 26: 207220.

Soria EA, Eynard AR, Bongiovanni GA 2010. Cytoprotective effects of silymarin on epithelial cells against arsenicinduced apoptosis in contrast with quercetin cytotoxicity. Life Sci 87: 309-315.

Sun G, Li X, Pi J, Sun Y, Li B, Jin Y, Xu YJ 2006. Current research problems of chronic arsenicosis in China. $J$ Health Popul Nutr 24: 176-181.

Tramonti G, Romiti N, Chieli E 2009. Albumin influences expression and function of the membrane transporter P-glycoprotein in HK-2 human proximal tubular cells. J Nephrol 22: 263-272.

\section{*Correspondence}

Gabino Garrido

Departamento de Química y Farmacia, Facultad de Ciencias, Universidad Católica del Norte Angamos 0610, Antofagasta, Chile.

ggarridog@ucn.cl 